\title{
PENGEMBANGAN INSTRUMEN KETERAMPILAN BERPIKIR KRITIS PADA PEMBELAJARAN IPA
}

\section{DEVELOPMENT OF CRITICAL THINKING SKILLS INSTRUMENTS IN LEARNING SAINS}

\author{
Jamaluddin, A. Wahab Jufri, Muhlis, dan Imam Bahtiar \\ Program Studi Pendidikan Biologi FKIP Unniversitas Mataram, Mataram, Indonesia \\ Email: jamaluddin.fkip@unram.ac.id
}

Diterima : 24 Juli 2019. Disetujui : 31 Desember 2019. Dipublikasikan: 31 Januari 2020

\begin{abstract}
Abstrak: Pengembangan Instrumen Keterampilan Berpikir Kritis Pada Pembelajaran IPA di SMP. Berpikir kritis adalah salah satu keterampilan berpikir tingkat tinggi yang perlu dilatih untuk peserta didik sehingga mereka memiliki kompetensi yang cukup dalam menghadapi masalah kehidupan yang semakin kompleks di era informasi dan globalisasi sekarang dan di masa depan. Tujuan penelitian ini adalah untuk mengembangkan instrumen keterampilan berpikir kritis yang dapat digunakan oleh pendidik untuk mengukur dan mengembangkan keterampilan berpikir kritis peserta didik melalui pembelajaran IPA SMP. Instrumen keterampilan berpikir kritis ini dikembangkan dengan mengacu pada model pengembangan Borg \& Gall. Instrumen ini telah divalidasi oleh seorang ahli pembelajaran dari FKIP Unram, dan pendidik di sekolah menengah. Pengembangan produk dalam bentuk instrumen tes keterampilan berpikir kritis melalui pembelajaran IPA Sekolah Menengah Pertama dengan karakteristik: 1) pertanyaan pilihan ganda dengan satu jawaban yang benar dari empat pilihan jawaban alternatif; 2) jumlah item adalah 30 item; 3) Tingkat kesulitan pada level sedang; 4) validitas pertanyaan adalah 0,74 (tinggi) pada $\mathrm{p}=0,05$; dan 5) releiabelitas soal adalah 0,85 (sangat reliabel).
\end{abstract}

Kata Kunci: Instrumen, Berpikir kritis, \& Pembelajaran IPA.

\begin{abstract}
Development of instruments for critical thinking skills At Science Learning in Middle School. Critical thinking ability is one of the high-level thinking skills that need to be trained for students so that they have sufficient competence in facing increasingly complex life problems in the information and globalization era now and in the future. The purpose of this study is to develop an instrument of critical thinking skills that can be used by educators in an effort to measure and develop students' critical thinking skills through junior high school science learning. This instrument of critical thinking ability was developed in reference to the development model of Borg \& Gall. This instrument has been validated by a learning expert from FKIP Unram, and educators in secondary schools. Product development in the form of a critical thinking ability test instrument through Middle School science lessons with characteristics: 1) multiple choice questions with one correct answer from four alternative answer choices; 2 ) the number of items is 30 items; 3 ) Level of difficulty at medium level; 4) the validity of the question is 0.74 (high) at $\mathrm{p}=0.05$; and 5) reliability of the test is 0.85 (very reliable).
\end{abstract}

Key word: Instrument, Critical Thinking, Learning Science.

\section{PENDAHULUAN}

Pendidikan IPA memegang peranan penting dalam mengembangkan pengetahuan, keterampilan berpikir, dan sikap peserta didik. Melalui pendidikan IPA peserta didik dapat mengenal, menyikapi dan mengapresiasi ilmu pengetahuan dan teknologi, serta menanamkan kebiasaan berpikir dan berprilaku ilmiah yang kritis, kreatif dan mandiri [1]. Dalam Perencanaan dan pelaksanaan pembelajaran IPA pendidik diharapkan dapat mengembangkan pemahaman konsep dan mengembangkan keterampilan berpikir tingkat tinggi peserta didik. Keterampilan berpikir adalah suatu kecakapan hidup yang sangat dibutuhkan peserta didik untuk dapat berkompetesi dalam meraih kehidupan yang layak di era globalisasi dan teknologi informasi yang berkembang dengan pesat saat ini dan masa yang akan datang.

Melalui pembelajaran IPA di SMP, pendidik perlu menanamkan kesadaran pada peserta didik bahwa IPA berhubungan dengan cara mencari tahu tentang rahasia alam secara sistematis. IPA bukan hanya kumpulan pengetahuan yang berupa fakta-fakta, konsepkonsep, atau prinsip-prinsip saja tetapi juga merupakan proses penemuan [2]. Pembelajaran IPA harus dirancang dan dilaksanakan untuk mengembangkan keterampilan berpikir tingkat tinggi peserta didik. Hal ini merupakan suatu proses penting agar mereka memiliki kecakapan hidup yang kompetitif untuk menghadapi masa depannya. Pembelajaran IPA tidak semata-semata 
berorientasi pada pemahaman produk IPA berupa konsep-konsep, prinsip-prinsip, teori-teori dan hukum-hukum alam. Hakekat pembelajaran IPA adalah agar peserta didik dapat menguasai produk IPA melalui suatu proses ilmiah yang dikenal dengan metode ilmiah. Melalui pembelajaran IPA pendidik dapat mengembangkan penguasaan konsep, keterampilan berpikir, dan sikap ilmiah peserta didik.

Salah satu keterampilan berpikir yang penting untuk dikembangkan pada peserta didik adalah keterampilan berpikir kritis. Keterampilan berpikir kritis merupakan keterampilan yang sangat essensial untuk kehidupan, pekerjaan dan berfungsi efektif dalam semua aspek kehidupan lainnya [3]. Demikian pula halnya dalam proses pembelajaran di SMP, keterampilan berpikir kritis dapat ditingkatkan. Globalisasi dan perkembangan IPTEK menunjukkan bahwa pengembangan keterampilan berpikir kritis peserta didik melalui pembelajaran merupakan suatu keharusan agar peserta didik dapat menyaring arus informasi yang demikian derasnya. Proses filterisasi informasi hanya dapat dilakukan dengan baik dan benar oleh para pemikir kritis.

Berpikir kritis merupakan proses terorganisir yang melibatkan aktifitas mental, diantaranya menganalisis asumsi, memunculkan inkuiri biologi dan pengambilan keputusan [3]. Peserta didik yang memiliki keterampilan berpikir kritis yang baik mampu membuat pertimbangan yang cermat dalam membuat keputusan untuk menerima atau menolak suatu pernyataan yang bersifat benar atau salah. Pengembangan keterampilan berpikir kritis merupakan integrasi beberapa bagian pengembangan keterampilan, seperti pengamatan (observasi), analisis, penalaran, penilaian, pengambilan keputusan, dan persuasi. Semakin baik baik keterampilan ini dikembangkan pada peserta didik maka akan semakinbaik pulah keterampilan mereka dalam melakukan pemecahan masalah yang komplek dengan hasil yang memuaskan.

Pengembangan keterampilan berpikir peserta didik bertujuan agar mereka dapat tumbuh menjadi Sumber Daya Manusia (SDM) yang mampu bertahan di tengah gelombang persaingan global di masa kini dan masa depannya yang semakin rumit dan demikian kompleksnya dalam berbagai aspek kehidupan masyarakat. Perkembangan dunia di era globalisasi membutuhkan SDM yang mampu berkompetisi dan sekaligus bekerja sama dengan SDM dari negara lain. Bangsa yang tidak siap berkompetisi akan tertinggal dalam segala bidang terutama bidang ilmu pengetahuan dan teknologi (IPTEK). Agar bangsa Indonesia mampu bersaing dengan bangsa lain sangat ditentukan oleh keunggulan SDM yang dihasilkan melalui proses pendidikan [4].
Pembelajaran yang berorientasi pada pengembangan keterampilan berpikir tingkat tinggi peserta didik diserahkan sepenuhnya kepada para pendidik melalui mata pelajaran yang mereka ajarkan di sekolah. Namun demikian dari hasil observasi menunjukkan bahwa para pendidik merancang dan melaksanakan pembelajaran hanya berorientasi pada penguasaan konsep, demikian pula dengan pembelajaran IPA di SMP. Dari rencana pembelajaran yang disusun menunjukkan bahwa pembelajaran pengembangan berpikir tingkat tinggi termasuk pengemabangan keterampilan berpikir kritis belum dilakukan dengan sengaja dan terencana untuk mengembangakan keterampilan berpikir kritis peserta didik. Demikian pula dengan alat evaluasi yang dikembangkan hanya berorientasi pada alat penilaian yang mengur penguasaan konsep IPA. Untuk itulah melalui penelitian dipandang perlu untuk mengembangkan instrumen untuk mengukur keterampilan berpikir kritis peserta didik melalui pembelajaran IPA di SMP.

Berdasarkan latar belakang masalah sebagaimana diungkap pada pada lata belakang, dapat diketahui bahwa pengembangan keterampilan berpikir kritis peserta didik melalui pembelajaran IPA menjadi sangat penting untuk mempersiapakan mereka menghadapi tantangan globalisasi dan perkembangan IPTEK dimasa kini dan dimasa yang akan datang. Terlebih lagi pada era informasi ini yang membutuhkan generasi generasi penerus yang memiliki keterampilan berpikir kritis tinggi.

Secara umum tujuan penelitian ini adalah untuk mengembangkan Instrumen tes keterampilan berpikir kritis peserta didik melalui pembelajaran IPA di SMP. Secara khusus penelitian ini bertujuan untuk: 1) menganalisis Kompetensi Inti (KI) dan Kompetensi Dasar pelajaran IPA SMP yang berpotensi untuk mengembangkan keterampilan berpikir kritis peserta didik melalui pembelajaran IPA di SMP; 2) mengembangkankisi-kisi instrument kemampuaberpikir kritis berdasarkan indikator berpikir kritis dari Ennis (1985); dan 3) mengembangkan instrumen tes keterampilan berpikir kritis pada pembelajaran IPA SMP/MTs yang merujuk pada inkator keterampilan berpikir kritis dari Ennis. Penelitian ini dipandang penting untuk dilakukan berdasarkan kenyataan dan pemikiran antara lain: 1) belum terencana dan terlaksananya pembelajaran IPA yang berorientasi pada pengembangan keterampilan berpikir kritis peserta didik sesuai dengan tuntutan kompetensi pada kurikulum 2013; 2) belum tersedianya intrumen keterampilan berpikir kritis dalam pembelajaran IPA yang dapat digunakan oleh pendidik untuk mengasses keterampilan berpikir kritis peserta didiknya.

Luaran penelitian ini berupa instrument tes keterampilan berpikir kritis pada pembelajaran 
IPA SMP/MTs. Produk lain yang dapat langsung dimanfaatkan dari hasil penelitian ini adalah berupa hasil analisis kompetensi dasar mata pelajaran IPA SMP/MTs Kurikulum 2013. Hasil analisis ini digunakan sebagai acuan untuk mengembangkan instrument tes keterampilan berpikir kritis peserta didik melalui pembelajaran IPA SMP dalam bentuk tes pilihan ganda. dan kunci jawabannya. Tes dimaksud disusun dengan materi pembelajaran IPA SMP yang terdiri atas 30 butir soal.

\section{METODE PENELITIAN}

Penelitian ini menggunakan pendekatan penelitian pengembangan dengan hasil akhir yang diperoleh adalah: 1) hasil analisis Kompetensi Inti (KI) dan Kompetensi Dasar pelajaran IPA SMP Kurikulum 2013 yang berpotensi untuk mengembangkan keterampilan berpikir kritis peserta didik melalui pembelajaran IPA di SMP; 2) kisi-kisi instrument keterampilan berpikir kritis berdasarkan indikator berpikir kritis dari Ennis.dan 3 instrumen keterampilan berpikir kritis dalam bentuk soal pilihan ganda mata pelajaran IPA yang merujuk pada inkator keterampilan berpikir kritis dari Ennis.

Prosedur penelitian pengembangan yang digunakan merujuk pada prosedur penelitian pengembangan Borg dan Gall (Depdiknas 2005). Langkah-langkah penelitian \& pengembangan dimaksud dapat digambarkan sebagai berikut: 1) melakukan studi pendahuluan (presurvey) untuk mengumpulkan informasi (kajian pustaka, pengematan kelas)., identifikasi permasalahan yang dijumpai dalam pembelajaran dan merangkum permasalahan; 2) melakukan perancanaan pengembangan produk; 3) mengembangkan produk awal, meliputi kajian materi pembelajaran, dan alat evaluasi; melakukan uji coba lapangan tahap awal, dilakukan pada 1 Sekolah. Menggunakan $30-60$ peserta didik yang mengikuti pelajaran IPA SMP; 4) elakukan revisi terhadap produk awal berdasarkan hasil uji lapangan; 5) melakukan uji coba lapangan utama dengan melibatkan 1 sekolah dengan 195 peserta didik; 6) melakukan revisi terhadap produk operasional berdasarkan hasil ujicoba lapangan utama. 7) desiminasi dan implemetasi produk, melaporkan dan mempublikasi melalui seminar, jurnal atau pertemuan ilmiah lainnya.

Data yang dikumpulkan berupa data kualitatif yang diperoleh saat melaksanakan setiap tahapan penelitian dan pengembangan. Data yang diperoleh akan dinarasikan sesuai dengan proses dan hasil yang diperoleh selama pengembangan produk sampai dengan tahapan ujicoba pemakaian. Teknik yang digunakan dalam penelitian pengembangan ini adalah teknik analisis data kualitatif dengan cara melakukan interpretasi terhadap deskripsi data yang diperoleh dari setiap tahapan pengembangan produk. Hasil interpretasi data ini akan digunakan untuk melakukan revisi produk pengembangan sehingga dihasilkan instrument keterampilan berpikir kritis peserta didik melalui pembelajaran IPA SMP.

\section{HASIL DAN PEMBAHASAN Hasil}

Produk penelitian dan pengembangan yang dihasilkan melalui penelitian ini terdiri atas: 1) Hasil analisis Kompetensi Inti (KI) dan Kompetensi Dasar pelajaran IPA SMP pada Standar isi Kurikulum 2013 edisi 2016, yang berpotensi untuk mengembangkan keterampilan berpikir kritis peserta didik melalui pembelajaran IPA di SMP; 2) Kisi-kisi instrument keterampilan berpikir kritis berdasarkan indikator berpikir kritis dari Ennis; 3) Instrumen keterampilan berpikir kritis dalam bentuk soal essai mata pelajaran IPA yang merujuk pada inkator keterampilan berpikir kritis dari Ennis.

Instrumen keterampilan berpikir kritis yang dikembangkan dalam penelitian ini merujuk pada pedoman penyusunan soal keterampilan berpikir tingkat tinggi (Hight Order Thinking Skill) yang diterbitkan oleh Direktorat Pembinaan SMA Direktorat Jenderal Pendidikan Dasar Dan Menengah, Departemen Pendidikan Dan Kebudayaan RI Tahun 2017. Prosedur pengembangan intrumen dimaksud melalui penelitian ini sebagai berikut.

\section{Hasil Analisis Potensi dan Masalah}

Penelitian pengembangan ini dimulai dari adanya potensi dan masalah yang terkait dengan sistem penilaian pada pembelajaran IPA di SMP. Dari hasil studi pendahuluan diketahui bahwa sistem penilaian yang dilaksanakan oleh pendidik IPA lebih menekan pada aspek penguasaan konsep IPA. Bentuk soal menuntut jawaban yang sifatnya hafalan. Soal-soal yang dikembangkan oleh pendidik sangat kurang menuntut jawaban yang berorientasi kepada keterampilan berpikir tingkat tinggi. Kegiatan pembelajaran IPA di SMP masih berorientasi pada penguasaan konsep, belum dirancang secara sengaja untuk mengembangkan keterampilan berpikir tingkat tinggi peserta didik. Potensi-potensi untuk mengembangkan keterampilan berpikir tingkat tinggi peserta didik melalui pembelajaran IPA cukup relevan dilihat dari sisi materi yang perlu dikuasai oleh peserta didik. Namun demikian para pendidik IPA di SMP belum memiliki keterampilan yang memadai untuk menyusun soal yang berbasis pada pengembangan keterampilan berpikir tingkat tinggi pesrta didik.

Dari hasil analisis perangkat pembelajaran IPA yang disusun oleh pendidik di SMP menunjukkan bahwa format dan isi dari perangkat pembelajaran belum merujuk pada Permendikbud nomor 22 tahun 2016. Implementasi Kurikulum 2013 mata pelajaran IPA SMP menghendaki 
kegiatan pembelajaran tidak hanya menekankan pada penguasaan konsep saja, tetapi juga mengembangkan keterampilan berpikir tingkat tinggi peserta didik. Dengan demikian pendididik juga diharapkan mampu mengembangkan soal-soal yang berorientasi untuk mengakses keterampilan berpikir tingkat tinggi peserta didik.

\section{Hasil Pengumpulan Informasi.}

Setelah potensi dan masalah yang terkait dengan instrumen keterampilan berpikir tingkat tinggi dapat teridentifikasi, selanjutnya tim peneliti mengumpulkan berbagai informasi yang dapat digunakan sebagai acuan untuk mengembangkan instrumen keterampilan berpikir tingkat tinggi peserta didik. Menurut Soal-soal keterampilan berpikir tingkat tinggi (HOTS) merupakan instrumen pengukuran yang digunakan untuk mengukur keterampilan berpikir tingkat tinggi, yaitu keterampilan berpikir yang tidak sekadar mengingat (recall), menyatakan kembali (restate), atau merujuk tanpa melakukan pengolahan (recite) [5]. Soal-soal HOTS pada konteks asesmen mengukur keterampilan: 1) transfer satu konsep ke konsep lainnya, 2) memproses dan menerapkan informasi, 3) mencari kaitan dari berbagai informasi yang berbeda-beda, 4) menggunakan informasi untuk menyelesaikan masalah, dan 5) menelaah ide dan informasi secara kritis. Meskipun demikian, soal-soal yang berbasis HOTS tidak berarti soal yang lebih sulit daripada soal recall. The Australian Council for Educational Research (ACER) menyatakan bahwa keterampilan berpikir tingkat tinggi merupakan proses: menganalisis, merefleksi, memberikan argumen alasan), menerapkan konsep pada situasi berbeda, menyusun, menciptakan. Keterampilan berpikir tingkat tinggi bukanlah keterampilan untuk mengingat, mengetahui, atau mengulang. Dengan demikian, jawaban soal-soal HOTS tidak tersurat secara eksplisit dalam stimulus [6].

Keterampilan berpikir tingkat tinggi termasuk keterampilan untuk memecahkan masalah (problem solving), keterampilan berpikir kritis (critical thinking), berpikir kreatif (creative thinking), keterampilan berargumen (reasoning), dan keterampilan mengambil keputusan (decision making). Keterampilan berpikir tingkat tinggi merupakan salah satu kompetensi penting dalam dunia modern, sehingga wajib dimiliki oleh setiap peserta didik. Oleh karena keterbatas dana dan waktu maka melalui penelitian hanya dibatasi pada pengembangan instrumen penilaian keterampilan berpikir kritis. Untuk penilaian yang dilakukan oleh sekolah seperti Ujian Sekolah (US) bentuk soal HOTS yang disarankan cukup 2 saja, yaitu bentuk pilihan ganda dan uraian. Melalui penelitian ini instrumen soal yang dikembangkan adalah instrumen soal bentuk pilihan ganda. Pengembangan soal dimasud mengacu pada Mudul penyusunan soal HOT's yang disusun oleh Warisdiono.

Pada umumnya soal-soal HOTS menggunakan stimulus yang bersumber pada situasi nyata. Soal pilihan ganda terdiri dari pokok soal (stem) dan pilihan jawaban (option). Pilihan jawaban terdiri atas kunci jawaban dan pengecoh (distractor). Kunci jawaban ialah jawaban yang benar atau paling benar. Pengecoh merupakan jawaban yang tidak benar, namun memungkinkan seseorang terkecoh untuk memilihnya apabila tidak menguasai bahannya/materi pelajarannya dengan baik. Jawaban yang diharapkan (kunci jawaban), umumnya tidak termuat secara eksplisit dalam stimulus atau bacaan. Peserta didik diminta untuk menemukan jawaban soal yang terkait dengan stimulus/bacaan menggunakan konsep-konsep pengetahuan yang dimiliki serta menggunakan logika/penalaran. Jawaban yang benar diberikan skor 1 , dan jawaban yang salah diberikan skor 0 .

Desain Instrumen Keterampilan Berpikir Kritis Desain instrumen keterampilan berpikir kritis yang dikembangkan melalui penelitian ini dengan tahapan-tahapan sebagai berikut. 1) analisis Kompetnsi Inti (KI) dan Kompetensi Dasar (KD) bertujuan untuk menentukan sejumlah KD yang berpotensi untuk dikembangkan menjadi butir soal keterampilan berpikir kritis. Hal ini akan dapat diketahui setelah dilakukan perumusan indikator pembelajaran. Analisis ini merujuk pada daftar KI dan KD Ilmu pengetahuan Alam SMP/MTs Kurikulum 2013 edisi revisi. KD yang dianalisis terdiri dari $10 \mathrm{KD}$ pada kelas VII dan VIII. Hasil analisis KI dan KD kurikulum IPA SMP/MTs; 2) Penyusunan instrument keterampilan berpikir kritis dengan langkahlangkah: Penentuan indikator soal berpikir kritis, Penyusunan kisi-kisi soal berpikir kritis, penyusunan butir-butir soal berpikir kritis, dan penyusunan kunci jawaban soal berpikir kritis. Indikator soal berpikir kritis yang digunakan adalah indikator keterampilan berpikir kritis. Indikator keterampilan berpikir kritis dimaksud terdiri dari 1) memberikan penjelasan sederhana; 2) membangun keterampilan dasar; 2) membangun keterampilan dasar; 3) membuat inferensi; 4) membuat penjelasan lebih lanjut; dan 5) mengatur strategi dan teknik [7]. Berdasarkan indicator tersebut kemudian disusunlah kisi-kisi soal keterampilan berpikir kritis. Dari kisi-kisi soal keterampilan berpikir kritis ini kemudian dirumuskan butir-butir soal keterampilan berpikir kritis pada pembelajran IPA SMP/MTs. Julah butir soal yang rumuskan terdiri dari 50 soal dalam bentuk pilihan ganda empat pilihan jawaban.

\section{Hasil Validasi Butir Soal}


Proses untuk mengetahui kelayakan instrumen keterampilan berpikir kritis yang telah dikembangkan dalam bentuk rancangan instrumen layak atau tidaknya, dilakukan dengan cara meminta pendapat para ahli yang berpengalaman dalam hal ini divalidasi oleh pakar pembelajaran dari FKIP Unram dan validasi oleh pengguna yaitu guru-guru SMP. Format yang digunakan untuk menelaah buir soal keterampilan berpikir tinggi (HOTs) merujuk pada instrument validasi soal keterampilan berpikir tingkat tinggi [6]. Hasil validasi ahli dan pengguna terhadap instrumrn keterampilan berpikir kritis menyatakan bahwa instrument tes keterampilan berpikir kritis layak digunakan setelah melakukann revisi pada beberapa butir soal.

\section{Hasil Uji coba lapangan butir soal pada Peserta didik SMP}

Uji coba lapangan butir soal keterampilan berpikir kritis dilakukan pada Peserta didik SMP kelas IX yang dikuti oleh 195 subjek ujicoba. Hasil ujicoba ini kemudian dianalisis menggunakan program analisis butir soal softwere ANATES dengan bantuan komputer. Dari hasil perhitungan dengan program ANATES dapat diketahui tentang validitas $=0,66$ pada $\mathrm{p}=0,05$, reliabilitas $=0,80$, tingkat kesukaran soal $=$ rata-rata sedang.

\section{Revisi Instrumen Keterampilan Berpikir Kritis}

Berdasarkan hasil validasi ahli, validasi pengguna, dan hasil uji coba pada peserta didik SMP telah dilakukan revisi instrument kemapuan berpikir kritis oleh tim peneliti. Dari 50 butir soal yang dianalis kemudian direvisi dengan cara membuang butir butir soal yang tidak signifikan atau tidak layak digunakan. Berdasrkan hasil analisis butir soal menggunakan program ANATES diperoleh 30 butir soal yang valid dan layak digunakan untuk mengukur keterampilan berpikir kritis peserta didik SMP/MTs. Dari hasil revisi instrumen tersebut dapat meningkatkan validitas butir soal $=0,74$ pada $\mathrm{p}=0,05$ (signifikan), reliabilitas $=0,85$ (sangat tinggi) dan tingkat kesukaran rata-rata sedang.

\section{Pembahasan}

Berpikir kritis adalah proses disiplin yang secara intelektual aktif dan terampil mengkonseptualisasi, menerapkan, menganalisis, mensintesis atau mengevaluasi informasi yang dikumpulkan atau dihasilkan oleh pengamatan, pengalaman, refleksi, penalaran atau komunikasi sebagai panduan untuk kepercayaan dan tindakan [8]. Berpikir kritis merupakan sebuah proses terorganisasi yang memungkinkan peserta didik mengevaluasi bukti, asumsi, logika dan bahasa yang mendasari pernyataan orang lain. Sesungguhnya keterampilan berpikir kritis adalah suatu proses berpikir yang terjadi pada seseorang yang bertujuan untuk membuat keputusan- keputusan yang rasional mengenai sesuatu yang dapat ia yakini kebenarannya.

Berpikir kritis dapat dengan mudah diperoleh apabila seseorang memiliki motivasi atau kecenderungan dan keterampilan yang dianggap sebagai sifat dan karakteristik pemikir kritis. Seseorang yang berpikir kritis memiliki karakter khusus yang dapat diidentifikasi dengan melihat bagaimana seseorang menyikapi suatu masalah. Screven dan Paul pada tahun 1987 memandang bahwa berpikir kritis sebagai proses disiplin cerdas secara aktif dan terampil dari konseptualisasi, penerapan, analisis, sintesa, dan mengevaluasi informasi yang diperoleh dari, atau dihasilkan oleh, pengamatan, pengalaman, refleksi, penalaran, atau komunikasi, sebagai panduan untuk keyakinan dan tindakan. Berpikir kritis merupakan salah satu kemapuan berpikir tingkat tinggi yang sangat dibutuh oleh peserta didik untuk menjadi generasi unggul dimasa depan. Keterampilan berpikir tingkat tinggi merupakan keterampilan yang sangat dibutuhkan oleh setiap warga negara untuk dapat mampu berkompetensi dalam persaingan global dimasa kini dan masa yang akan datang. Keterampilan berpikir dimaksud diantaranya adalah keterampilan berpikir kritis, kreatif, metakognisi, dan pemecahan masalah.

Pemerintah melalui Kementerian Pendidikan dan Kebudayaan mengharapkan dalam penerapan kurikulum 2013 agar pendidik mengembangkan keterampilan berpikir tingkat tinggi pesrta didik melalui kegiatan pembelajaran, termasuk melalui pembelajran IPA di SMP/MTs. Keseriusan pemerintah untuk mengembangkan keterampilan berpikir tingkat tinggi peserta didik ditunjukkan dengan berbagai upaya diantaranya dengan menerbit Modul Pedoman Pengembangan Tes Keterampilan Berpikir Tingka Tinggi (HOTs). Dalam Modul ini telah dijelaskan dengan rinci tentang konsep dan prosedur pengembangan Butir soal HOTs.

Hasil observasi Pembelajaran IPA di SMP menunjukkan bahwa pembelajaran masih berorientasi pada pengembangan keterampilan berpikir tingkat rendah dan tingkat sedang. Beberapa Kendala yang dialami oleh pendidik dalam pembelajaran diantaranya adalah model pembelajaran yang digunakan belum memberikan peluang yang cukup bagi peserta didik untuk berlatih berpikir tingkat tinggi. Orientasi pebelajaran masih didominasi oleh mengingat fakta atau menghafal konsep. Disisi lainnya potensi peserta didik untuk berlatih berpikir tingkat tinggi melalui pembelajaran IPA sangat memungkinkan. Permasalah lainnya pendidik masih mengalami masalah dalam mengembangkan instrument untuk mengukur keterampilan berpikir tingkat tinggi peserta didik termasuk dalam mengukur keterampilan berpikir kritis. 
Melalui penelitian ini telah dikembangkan instrumen tes keterampilan berpikir kritis peserta didik melalui pembelajaran IPA SMP/MTs. Instrumen dimaksud pada awalnya berjumlah 50 butir soal. Atas dasar hasil validasi oleh pakar pembelajaran dar kalangan dosen pembelajaran di FKIP Unram, dan hasil telaah dari guru-guru SMP. Kemudian intrumen tersebut diaujicobakan pada 195 peserta didik di SMP. Dilakukan revisi terhadap butir-butir soal yang tidak memenuhi syarat sebagai butir soal keterampilan berpikir kritis, dan pada akhirnya diperoleh 30 butir soal yang valid dan layak digunakan untuk mengases keterampilan berpikir kritis peserta didik melalui pembelajaran IPA SMP.

Karakteristik dari Inatrumen keterampilan berpikir kritis yang dikembangkan melalui penelitian ini adalah: 1) Instrumen tersebut digunakan untuk mengukur keterampilan berpikir kritis peserta didik SMP kelas VII dan kelas VIII; Jumlah Butir soal 30 butir; 3) Terdiri atas empat pilihan alternative jawaban dengan hanya satu jawaban benar; Untuk setiap butir soal yang dijawab benar diberikan skor 1 (satu), dan jawaban salah diberikan skor 0 (Nol).

Hasil validasi oleh Pakar pembelajaran dari FKIP Unram menunjukkan bahwa instrument tersebut secara rata-rata memenuhi kriteria sebagai soal keterampilan berpikir kritis dan layak digunakan dengan sedikit revisi. Demikian pula dengan hasil telaah dan validasi oleh pengguna dalam hal ini pendidik IPA di SMP sejumlah 3 orang. Ketiganya menyatakan bahwa instrument tersebut layak digunakan untuk mengukur keterampilan berpikir kritis peserta didik di SMP melalui pembelajaran IPA pada kelas VII dan Kelas VIII. Beberapa catatan yang diperoleh diantaranya perlu revisi terhadap gambar-gambar yang berkitan dengan materi IPA SMP untuk diperjelas, agar peserta didik dapat menganalisisnya dengan lebih tepat. Demikian pula dengan redaksi kalimat dari beberapa butir soal perlu disederhanakan sesuai dengan tingkat perkembangan peserta didik di SMP.

Hasil ujicoba lapangan dengan melibatkan 195 peserta didik. Hasil tes dianalisis menggunakan program ANATES menunjukkan bahwa validitas rata-rata butir soal adalah 0,66 (valid pada alfa 0,05 ), reliabilitas butur soal adalah 0,80 (katgori sangat tinggi) artinya soal tersebut dapat digunakan untuk mengukur keterampilan berpikir kritis peserta didik SMP pada subjek yang lain. Daya pembeda menunjukkan 11 butir soal dengan kategori mudah, 4 butir soal sangat mudah, 31 butir soal dengankategori sedang, dan 4 butir soal dengan kategori sukar. Atas dasar pertimbangan hasil validasi dan ujicoba lapangan maka dilakukan revisi pada instrument tersebut dengan cara membuang semua soal yang tidak valid.

Atas dasar pertimbangan waktu yang terbatas untuk setiap mata pelajaran maka ditentukan jumlah butir soal yang digunakan adalah 30 butir soal. Dengan demikian kegiatan penelitian dan pengembangan yang telah dilaksanakan ini menghasilkan produk pengembangan berupa instrumen keterampilan berpikir kritis yang terdiri dari indikator keterampilan berpikir kritis, kisi-kisi keterampilan berpikir kritis, instrument tes keterampilan berpikir kritis yang disertai dengan kunci jawabannya.

\section{KESIMPULAN}

Pengembangan instrumen tes keterampilan berpikir kritis dilakukan melalui tahapan: 1) menganalisis Kompetensi Inti (KI) dan Kompetensi Dasar pelajaran IPA SMP; 2) mengembangkan kisi-kisi instrument keterampilan berpikir kritis berdasarkan indikator berpikir kritis dari Ennis; 3) mengembangkan instrumen dalam bentuk soal pilihan ganda mata pelajaran IPA SMP. Produk pengembangan terdiri atas: 1) Hasil analisis Kompetensi Inti (KI) dan Kompetensi Dasar pelajaran IPA SMP pada Standar isi Kurikulum 2013 edisi 2016, 2) Kisi-kisi instrument keterampilan berpikir kritis berdasarkan indikator berpikir kritis dari Ennis; 3) Instrumen keterampilan berpikir kritis mata pelajaran IPA. 4) kunci jawaban hasil tes keterampilan berpikir kritis.

Karakteristik dari instrument tes keterampilan berpikir kritis melalui pembelajaran IPA SMP adalah: 1) bentuk soal pilihan ganda dengan satu jawaban benar dari empat alternatif pilihan jawaban; 2) jumlah butir soal adalah 30 butir soal; 3) Tingkat kesukaran soal rata-rata sedang; 4) validitas soal adalah 0,74 (tinggi); dan 5) reliabilatas soal adalah 0,85 (sangat reliable).

Produk penelitian dan pengembangan ini berupa instrument tes keterampilan berpikir kritis untuk peserta didik dengan materi IPA SMP. Produk dimaksud dapat digunakan sebagai salah satu rujukan yang dapat dicontoh untuk mengembangkan tes keterampilan berpikir tingkat tinggi lainnya seperti keterampilan berpikir kreatif, berpikir logis dan berpikir kompleks lainnya.

\section{DAFTAR PUSTAKA}

[1] BNSP. 2006. Standar Isi Untuk Satuan Pendidikan Dasar dan Menengah. Jakarta: Badan Standar Nasional Pendidikan.

[2] Susilawati, S., Jamaluddin, J., \& Bachtiar, I. (2017). Pengaruh model pembelajaran berbasis masalah (PBM) berbantuan multimedia terhadap kemampuan berpikir kritis peserta didik kelas vii smp negeri 2 mataram ditinjau dari kemampuan akademik. Jurnal Pijar Mipa, 12(2), 64-70.

[3] Nurmalia, C. 2009. Keterampilan Berpikir Kritis, Metakognisi dan hasil Belajar Biologi Peserta didik SMP Negeri di Kota Malang. Disertasi, tidak diterbitkan. Malang: Program Pascasarjana Universitas Negeri Malang. 
[4] Suryaningsih, S., Muhlis, M., \& Jamaluddin, J. (2017). EFEKTIVITAS PENGGUNAAN MODUL KERANG MUTIARA BERBASIS PENDEKATAN SAINTIFIK TERHADAP HASIL BELAJAR SISWA PADA MATA PELAJARAN BUDIDAYA DI SMKN 1 LEMBAR. Jurnal Pijar Mipa, 12(2), 60-63.

[5] Hamdi, S., Suganda, I. A., \& Hayati, N. (2018). Developing higher-order thinking skill (HOTS) test instrument using Lombok local cultures as contexts for junior secondary school mathematics. REiD (Research and Evaluation in Education), 4(2), 126-135.
[6] Kemndikbud, 2017. Modul Penyusunan Soal Higher Order Thinking Skills (HOTS). Jakarta: Direktorat Pembinaan SMA Ditjen Pendidikan Dasar dan Menengah.

[7] Ennis, R. 1985. Goals For Critical Thingking Curriculum. In A.L. Costa, Developing Minds: A Resource Book for Teaching Thinking. Alexandria: Association for Supervisor and Curriculum Development (ASCD).

[8] Tawil, M., \& Liliasari. 2013. Berpikir Kompleks dan Implementasinya dalam Pembelajaran IPA. Makassar: Badan Penerbit UNM. 